\title{
地盤表面に生ずる鉛直ひずみの 地震観測結果とその考察
}

\author{
森地 重暉 $^{1}$ ・菰田 陽一 ${ }^{2}$. 稲垣 裕久 $^{3}$ ・伊丹 博之 ${ }^{4}$ \\ 1正会員 東京理科大学教授 理工学部土木工学科（干278-8510 千葉県野田市山崎2641） \\ E-mail : morichi@rs.noda.tus.ac.jp \\ 2非会員 千葉県庁（干260-8667 千葉県千葉市中央区市場町1-1） \\ 3非会員 前田道路株式会社（干141-0032 東京都品川区大崎 1-11-3） \\ 4学生員 東京理科大学大学院理工学研究科土木工学専攻（广278-8510 千葉県野田市山崎2641）
}

\begin{abstract}
地盤内に生ずるひずみは 6 成分，地盤表面では 4 成分ある. 著者は地盤表面の 3 成分のひずみの地震観 測を継続してきた，更に鉛直方向の軸ひずみを観測すれば，地盤ひずみについて究明を深める ことが出来ると考え, ゲージ長 $1 \mathrm{~m}$ での観測を試行した. 幾つかの地震記録を得ることが出来た. 鉛直 方向の軸ひずみは，地表面の主ひずみと同程度の大きさがあり，上向きに座標軸をとると，鉛直方向の加 速度波形と逆位相を示す傾向があった。
\end{abstract}

Key Words : earthquake observation, ground strain, vertical normal strain

\section{1. はじめに}

地震時に地上構造物が加速度の影響を受けるに対して, 地中構造物は周辺地盤の動きに支配される. それ故に, 地中構造物の而震性を究明するには，地震時に生ずる地 盤ひずみの調査が基礎的であると考える. 通常, 地盤の 地震時挙動を調べるには，地盤速度や加速度の観測が行 われる．地盤ひずみを求めることで地盤の地震動挙動の 究明が深まると考えられる.

著者らは，直接にひずみを求めるよう観測を行って きた1). 地表面に拡がった辺長 $1 \mathrm{~m} の$ 正三角形を想定し， 各頂点位置に鉄杭を打ち込み, 杭間の相対変位を変位 計で測定した。このように，ゲージ長 $1 \mathrm{~m} の$ 地盤表面 の3方向の軸ひずみを観測した。観測結果を調査した 結果，ひずみは純せん断状態であること，主ひずみ方 向には地盤特有の卓越したものがあることなどが明ら かになった。

ひずみは地盤内で6成分あり，地表面では4成分ある. 本観測では，地表面で3成分に対して行ってきたことに なる，そこで，地盤ひずみの究明を深めるために，鉛直 方向の軸ひずみの観測を試行した．若干の記録を得るこ とが出来たので報告する.

\section{2. 観測方法}

観測場所は千葉県野田市にある東京理科大学構内とし た．地表面における3方向の地震時に生ずる軸ひずみの 観測を継続している，ゲージ長は1mとした．1988年に 観測を開始したが，その観測場所から約 $100 \mathrm{~m} の$ 位置に 同様の観測施設を作り，広い範囲でのひずみの観測を行 った．観測した地盤の性状は前報1)に示した通りで，表 土，凝灰質粘土，細砂，砂混じりシルトと堆積したもの である．本文では，1つの観測施設で，鈆直方向のひず みの観測を試行した。

鈶直ひずみを観測するために，図-1に示すような工夫 を施した。ゲージ長は1mを目標とした。観測場所で直 径 $10 \mathrm{~cm}$ の縦穴をオーガーにより掘削した. 周辺の土が 崩落しないように，アルミダクトで縦穴の周りを覆つた. 縦穴底部に鋼製パイプを取り付けた。直径 $10 \mathrm{~cm}$, 厚さ $20 \mathrm{~mm}$ の鋼製の円盤に先端が尖った鋼棒を取り付け，こ の大きな画鋲状の金具に鋼製パイプを溶接した。画鋲状 のものを縦穴底部に打ち付けて固定した. 鋼棒先と地表 部の相対変位を測定すれば，縦穴底部と地表との相対変 位を求めることになる．地表部に大きな画鋲状の $2 つ の$ 金具を打ち込んだ. 各金具にネジ棒を立て2つのネジ棒 で鋼製チャンネルを連結した. チャンネルに変位計を取 


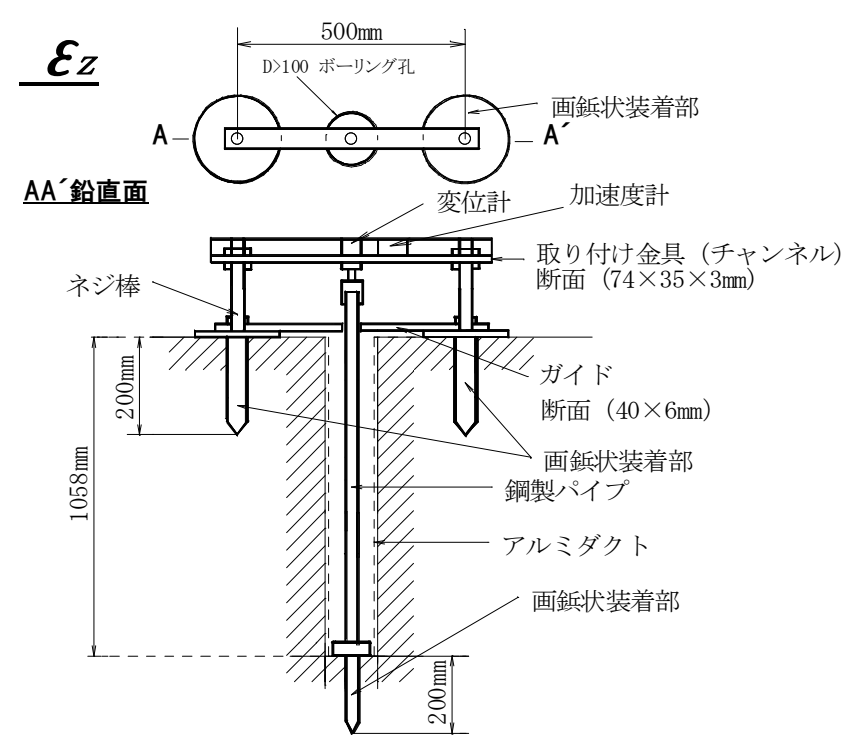

図-1 鉛直ひずみ計

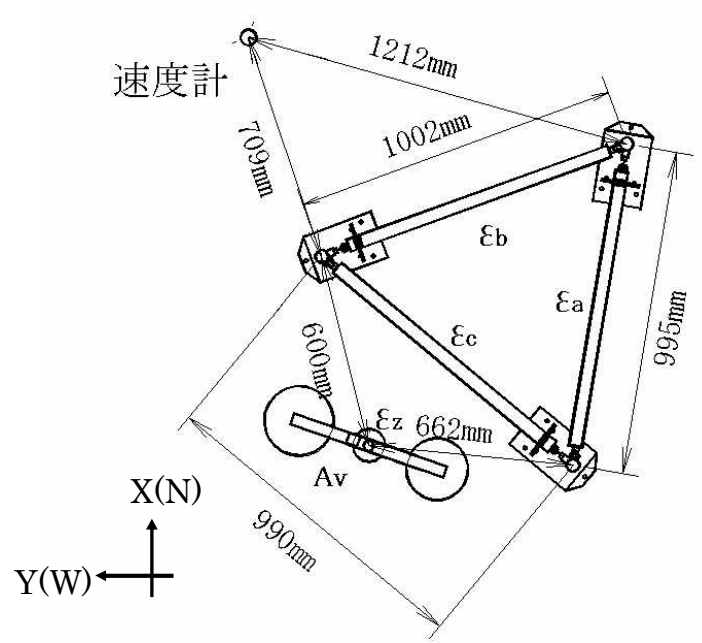

図-2 観測施設
り付け，鋼製パイプ先端と連結し，パイプ先端の変位を 観測した. このようにして, 縦穴底部と地表との相対変 位を観測し，底部と表面との間隔で除することで鉛直ひ ずみを求めた。

当該観測施設での観測状況を図-2に示寸。このように して，この観測施設での地表面に生ずる3方向の軸ひず み $\varepsilon_{a} ， \varepsilon_{b}, \varepsilon_{c}$ と鉛直ひずみ $\varepsilon_{z}$ の計4成分並びに地盤速度・ 加速度を観測した。

\section{3. 観測結果と考察}

図-3に観測結果 $\varepsilon_{z}$ の時刻歴の一例を示寸。地盤表面で 観測した3方向の軸ひずみより求めた図-2の方向で示す $\mathrm{x}$, $\mathrm{y}$ 方向の軸ひずみ $\varepsilon_{x}$ と $\varepsilon_{y}$, せん断ひずみ $\gamma_{x y}$ の時刻歴を併記 する．また，地表面での主ひずみ\&， $\varepsilon_{2}$ 及び $\gamma_{\max }$ をも併 記する. 真北 $\mathrm{N} の$ 方向にx 軸を取り, 西方向にy軸，上向 きに軸をとる.

図-3に示寸例について述べると，前震においては，鋁 直ひずみ瓜は地盤表面で生じたひずみよりも大きな振幅 を示すことが分かる．また， $\varepsilon_{z}$ の時刻歴最大值は地表面 の主ひずみのものと同程度で, 最大せん断ひずみの約 1/2程度であるといえる.

地盤表面では，ひずみは4成分ある，地盤表面と直 交する鉛直面内では，鉛直ひずみが主ひずみになる。 地盤表面方向の主ひずみは2成分あり，このために3成 分の主ひずみが求められ, モールひずみ円を描くこ とが出来る１1/100秒毎のモール円を図-4に示寸．太 めの線で描かれた円は地表面のひずみより得られた

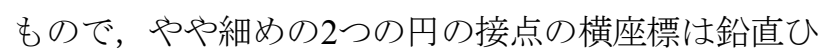

ずみを示す，なお，黒丸の横座標は $\varepsilon_{x}$, 縦座標は $-\gamma / 2$ を示す。

表-1に地盤加速度の合成值の最大時刻歴振幅が10gal以 上の地震記録について， $\varepsilon_{2}$ の時刻歴最大振幅を地表面で の $\gamma_{\max }$ と主ひずみの絶対值の最大值のものと比較し示す. また, 表示の地震について, 横軸に地盤加速度或いは地 盤速度を，縦軸に最大せん断ひずみ，主ひずみの絶対值， 鉛直ひずみを図-5に示す，本観測結果で得られた最大の 鉛直ひずみは $28.3 \mu$ であって, 最大せん断ひずみ $54.8 \mu$ の

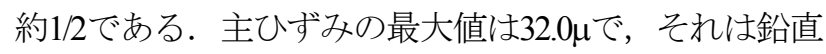
ひずみと同程度である.このときの地盤加速度は295gal であった．他の記録でも，最大せん断ひずみの值が最大 で，主ひずみと鉛直ひずみとの值はその約半分近くにな っている．表-1に示すNo.10と11の地震では，鉛直ひず みが最大せん断ひずみや主ひずみの值より著しく大きい. これら2つの地震では, 初動部で鉛直ひずみの急な立ち 上がりがあり，それを除けば，他の地震と同じような結 果を示した.

鉛直ひずみと鉛直加速度の時刻歴の比較を行った.

図一に示す通り，地盤に生ずる鉛直ひずみは鉛直加速度 と時刻歴が逆位相を示すように見える. 試みに，地盤表 面に生ずる3方向の軸ひずみと同一方向の軸ひずみを比 較したが，逆位相のようには見えない．また，鉛直ひず みと鉛直加速度とのフーリエスペクトルは類似している のに対して, 水平ひずみと同方向の加速度については類 似性がないと云える（図-7）。

鉛直ひずみと鉛直加速度との時刻歷に関する検討を 深めるために，1/100秒毎での波形の積が異符号になる 

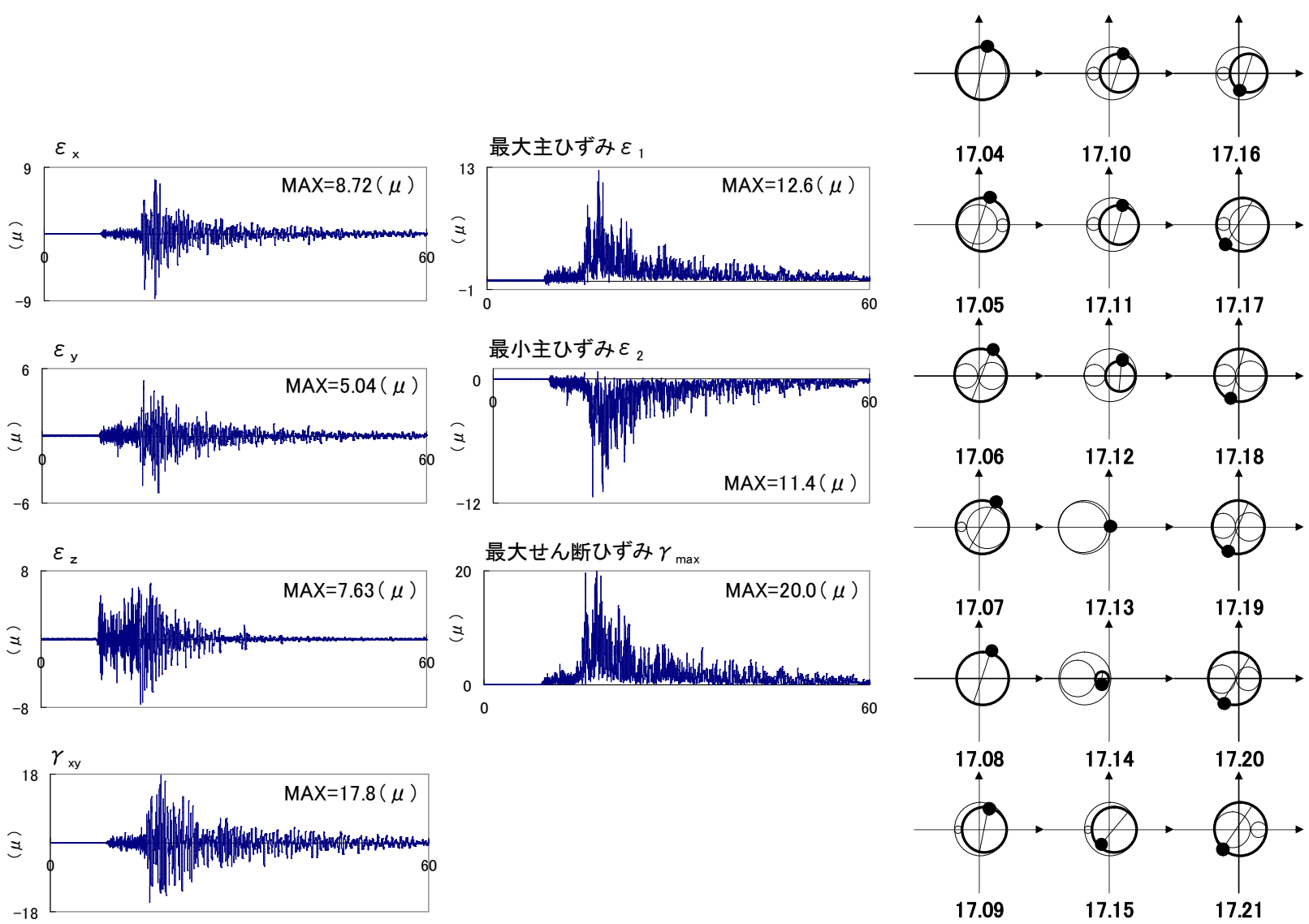

図-3 地盤ひずみの時刻歴波形（2005年 10 月 16 日）

図-4 モールひずみ円

(主要動部 : 17.04 17.21 秒)
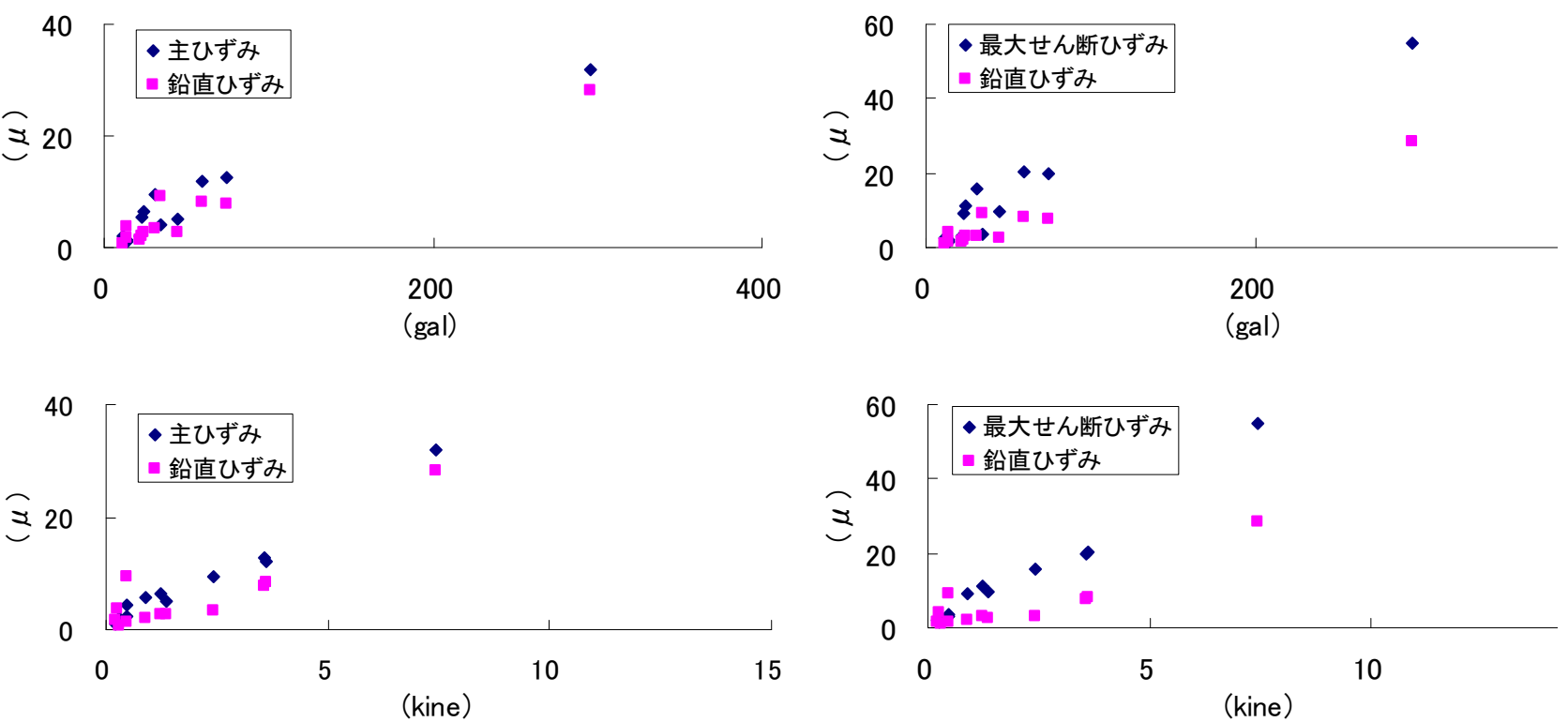

図-5 地盤加速度，地盤速度と主ひずみの絶対值，最大せん断ひずみ，鉛直ひずみとの関係 
表-1＼cjkstart地震記録

\begin{tabular}{|c|c|c|c|c|c|c|c|c|c|c|}
\hline \multirow{3}{*}{ NO. } & 日時 & \multicolumn{2}{|l|}{ 震央 } & \multirow{3}{*}{$\begin{array}{l}\text { 震源 } \\
\text { 深さ } \\
(\mathrm{km})\end{array}$} & \multirow{3}{*}{ M } & \multicolumn{5}{|c|}{ 最大值 } \\
\hline & \multirow{2}{*}{$\begin{array}{l}\text { 日付 } \\
\text { 時間 }\end{array}$} & 場所 & \multirow{2}{*}{ 距離 } & & & \multirow{2}{*}{$\frac{\frac{\text { 加速度 }}{\text { (gal) }}}{}$} & \multirow{2}{*}{$\frac{\text { 速度 }}{\text { (kine) }}$} & \multicolumn{3}{|c|}{ ひずみ } \\
\hline & & 北緯/東経 & & & & & & $\varepsilon(\mu)$ & $\gamma(\mu)$ & $\varepsilon_{z}(\mu)$ \\
\hline \multirow{2}{*}{1} & $2005 / 2 / 8$ & 茨城県南部 & \multirow{2}{*}{26} & \multirow{2}{*}{70} & \multirow{2}{*}{4.8} & \multirow{2}{*}{44.8} & \multirow{2}{*}{1.35} & \multirow[b]{2}{*}{ 5. 0} & \multirow{2}{*}{9.6} & \multirow[b]{2}{*}{2.6} \\
\hline & $11: 29: 28$ & $\begin{array}{|ccc|}36^{\circ} & 06.0^{\prime} & \mathrm{N} \\
140^{\circ} & 06.0^{\prime} & \mathrm{E}\end{array}$ & & & & & & & & \\
\hline \multirow[b]{2}{*}{2} & $2005 / 2 / 16$ & 茨城県南部 & \multirow[b]{2}{*}{9} & \multirow[b]{2}{*}{40} & \multirow[b]{2}{*}{5.4} & \multirow[b]{2}{*}{295} & \multirow[b]{2}{*}{ 7. 42} & \multirow[b]{2}{*}{32.0} & \multirow[b]{2}{*}{54.8} & \multirow[b]{2}{*}{28.3} \\
\hline & $4: 46: 36$ & $\begin{array}{|ccc|}36^{\circ} & 00.0^{\prime} & \mathrm{N} \\
139^{\circ} & 54.0^{\prime} & \mathrm{E} \\
\end{array}$ & & & & & & & & \\
\hline \multirow{2}{*}{3} & $2005 / 7 / 23$ & 千葉県北西部 & & & & & & & & \\
\hline & $16: 34: 56$ & $\begin{array}{|ccc|}35^{\circ} & 30.0^{\prime} & \mathrm{N} \\
140^{\circ} & 08.0^{\prime} & \mathrm{E} \\
\end{array}$ & 50 & 90 & 5.7 & 59.2 & 3.63 & 12.0 & 20.4 & 8.2 \\
\hline & $2005 / 8 / 16$ & 宮城県沖 & & & & & & & & \\
\hline 4 & $11: 46: 25$ & $\begin{array}{|ccc|}38^{\circ} & 06.0^{\prime} & \mathrm{N} \\
142^{\circ} & 18.0^{\prime} & \mathrm{E} \\
\end{array}$ & 321 & 42 & 7.2 & 30.9 & 2. 42 & 9.3 & 15.9 & 3.3 \\
\hline & $2005 / 10 / 16$ & 茨城県南部 & & & & & & & & \\
\hline 5 & $16: 05: 42$ & $\begin{array}{|ccc|}36^{\circ} & 00.0^{\prime} & \mathrm{N} \\
139^{\circ} & 54.0^{\prime} & \mathrm{E} \\
\end{array}$ & 9 & 47 & 5.1 & 74.7 & 3.58 & 12.6 & 20.0 & 7.6 \\
\hline & $2005 / 10 / 19$ & 茨城県沖 & & & & & & & & \\
\hline 6 & $20: 44: 00$ & $\begin{array}{|ccc|}36^{\circ} & 24.0^{\prime} & \mathrm{N} \\
141^{\circ} & 00.0^{\prime} & \mathrm{E} \\
\end{array}$ & 111 & 40 & 6.2 & 24.1 & 1.23 & 6.4 & 11.4 & 2.8 \\
\hline & $2005 / 12 / 2$ & 茨城県南部 & & & & & & & & \\
\hline 7 & $21: 54: 39$ & $\begin{array}{|ccc|}36^{\circ} & 12.0^{\prime} & \mathrm{N} \\
139^{\circ} & 48.0^{\prime} & \mathrm{E} \\
\end{array}$ & 33 & 50 & 4.3 & 13.6 & 0.21 & 1.1 & 1.8 & 1.8 \\
\hline & $2006 / 4 / 20$ & 杤木県南部 & & & & & & & & \\
\hline 8 & $12: 40: 20$ & $\begin{array}{|ccc|}36^{\circ} & 12.0^{\prime} & \mathrm{N} \\
139^{\circ} & 48.0^{\prime} & \mathrm{E} \\
\end{array}$ & 88 & 58 & 4.3 & 21.8 & 0.45 & 2.2 & 3. 2 & 1.3 \\
\hline & $2006 / 5 / 1$ & 茨城県南部 & & & & & & & & \\
\hline 9 & $16: 00: 43$ & $\begin{array}{|ccc|}36^{\circ} & 06.0^{\prime} & \mathrm{N} \\
139^{\circ} & 42.0^{\prime} & \mathrm{E} \\
\end{array}$ & 28 & 59 & 4.4 & 12.0 & 0.28 & 1.9 & 2. 4 & 0.8 \\
\hline & $2006 / 7 / 6$ & 茨城県南部 & & & & & & & & \\
\hline 10 & $15: 17: 28$ & $\begin{array}{|ccc|}36^{\circ} & 06.0^{\prime} & \mathrm{N} \\
140^{\circ} & 00.0^{\prime} & \mathrm{E} \\
\end{array}$ & 22 & 50 & 4.0 & 34.3 & 0.48 & 4.2 & 3.5 & 9.3 \\
\hline & $2006 / 7 / 30$ & 茨城県南部 & & & & & & & & \\
\hline 11 & $2: 19: 22$ & $\begin{array}{|cccc|}36^{\circ} & 12.0^{\prime} & \mathrm{N} \\
140^{\circ} & 06.0^{\prime} & \mathrm{E} \\
\end{array}$ & 35 & 52 & 3.9 & 13.9 & 0.24 & 1.3 & 1.7 & 3.8 \\
\hline & $2006 / 8 / 31$ & 東京湾 & & & & & & & & \\
\hline 12 & $17: 18: 18$ & $\begin{array}{|ccc|}35^{\circ} & 36.0^{\prime} & \mathrm{N} \\
140^{\circ} & 00.0^{\prime} & \mathrm{E}\end{array}$ & 30 & 10 & 4.8 & 22.5 & 0.90 & 0.0 & 9.0 & 2.1 \\
\hline
\end{tabular}

* No.2の地震では加速度, 速度は STRAIN-4の位置より $15 \mathrm{~m}$ 程度はなれた位置で測った.

\section{$z$ 方向}

25

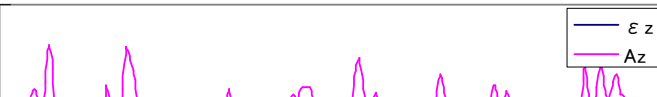

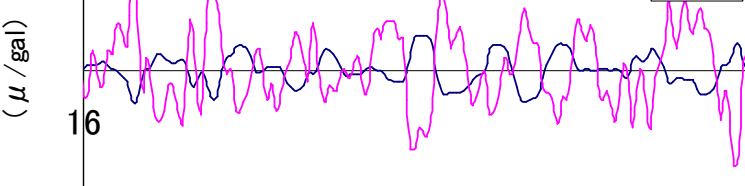

$-25$

\section{b方向}

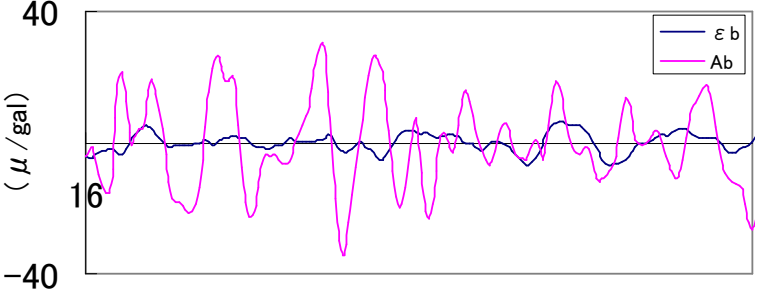

a方向

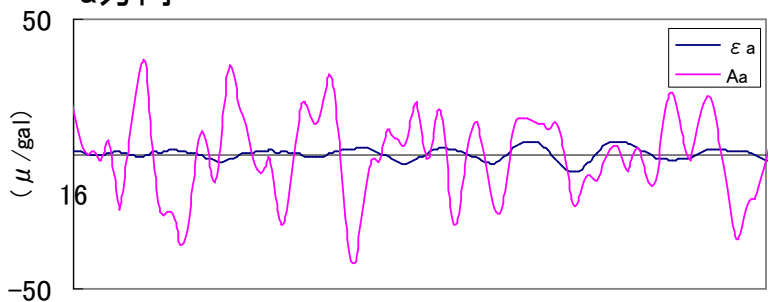

c方向

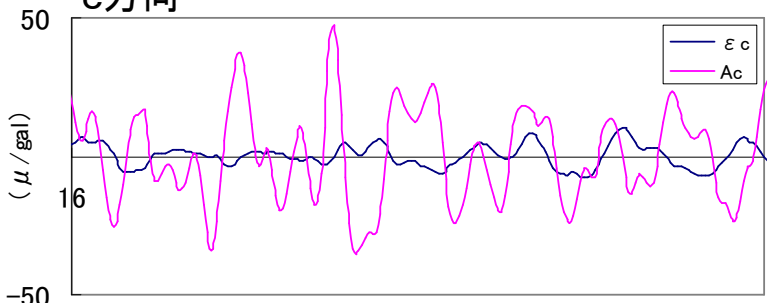

図-6 鉛直加速度とひずみの時刻歴波形（2005年 10 月 16 日，主要動部：16〜18秒） 

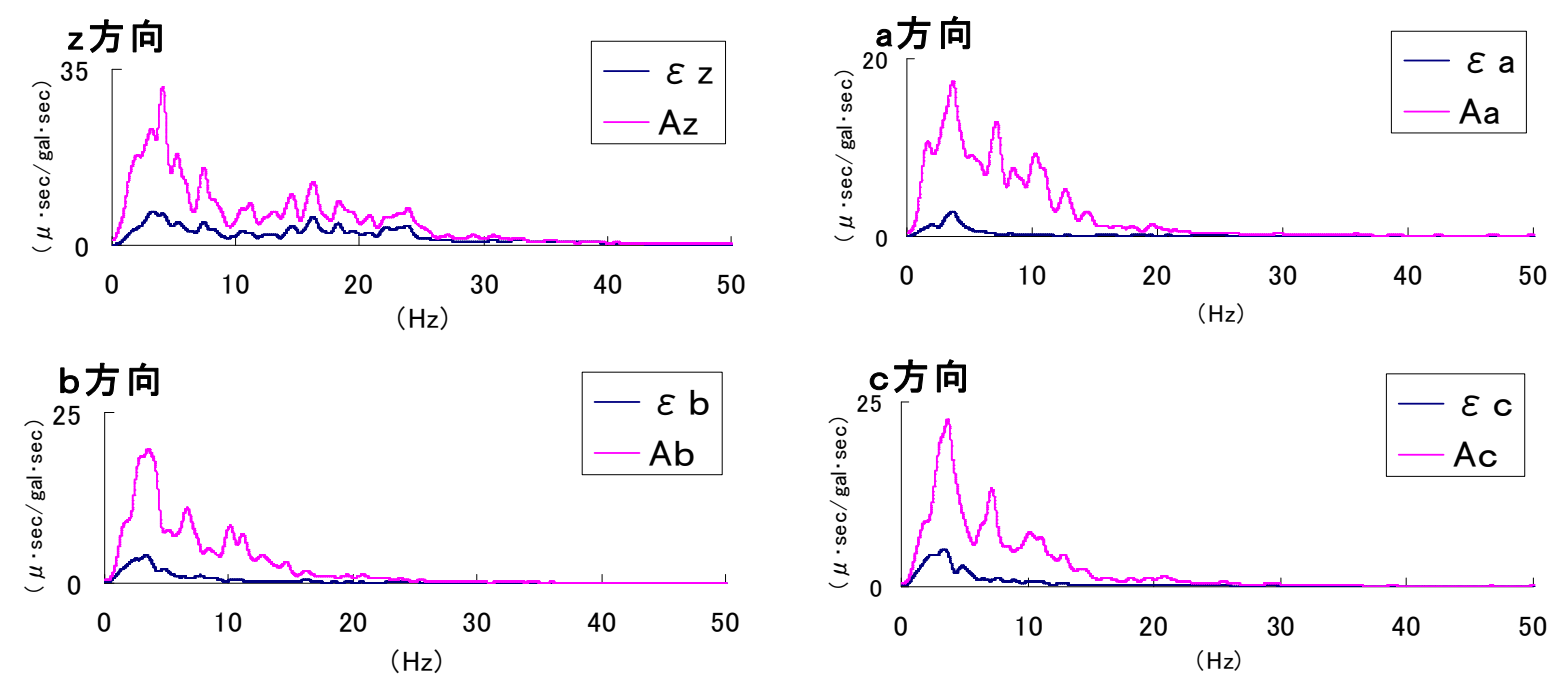

図-7加速度とひずみのフーリエスペクトル

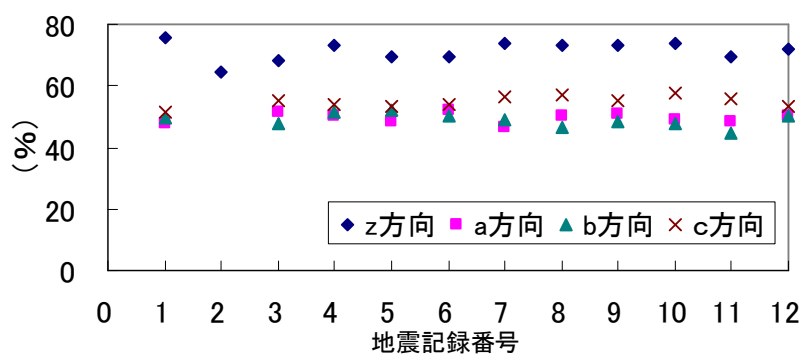

*地震記録 No. 2 は速度計の水平成分が振り切れのため算定不可.

図-8 加速度とひずタが異符号になる確率

割合を地震記録ごとに調べてみた。もし，波形が逆相 で似たものでなければ，異符号になる割合は50\%に近 いと考える．図-8にその結果を示す．地盤表面でのひ ずみと加速度との比較では $50 \%$ 近くを示すが，鉛直方 向の両者の比較では明らかに70-80\%になっている.

極めて単純に鉛直方向の変位 $U_{z}$ を次のように仮定す る. Z軸を上向きとする.

$$
U_{z}=B \cdot \exp (a z) \cdot \exp (i \omega t)
$$

式中, $B$ : 振幅, $a$ : 正の定数, $\omega:$ 円振動数, $t:$ 時間, $i:$ 虚数単位 である.

上式をzで偏微分するとz方向のひずみが，tで度偏微 分するとz方向の加速度が得られ，互いに異符号になる ことが分かる。

上述の通り，鉛直方向のひずみは主ひずみと同程度 であること，また，鈶直加速度と逆位相を示寸ことが

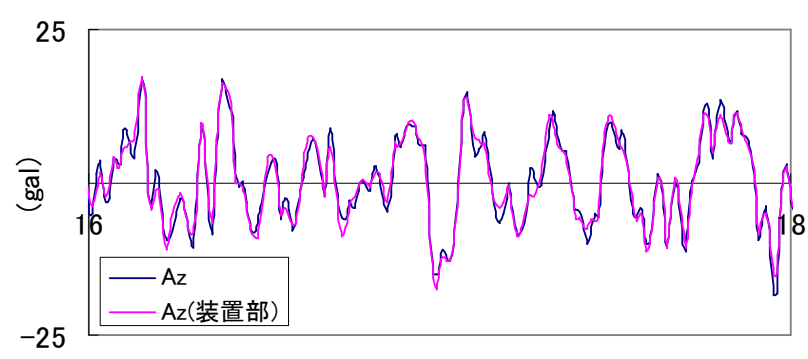

図-9 加速度時刻歴の比較（2005年 10 月 16 日）
あると云える.

\section{4. 観測方法の追認}

本方法では, 地表面と地表面下 $1 \mathrm{~m}$ 程度の縦穴底部と の相対変位を観測している. このような方法で行う以 上，地表面部に図-1 に示すような装置を必要とする. 問題は，その装置が固有振動を呈さず，忠実に地盤表 面の動きを示すかである. この問題に対する検討のた めに, 近くに埋め込んだ速度計から得られた加速度記 録と装置の加速度記録とに差異がないか調べた. 図-9 に両者の加速度記録を併記し示寸，両者の間に差異は 殆ど認められなかった。若干差異のある時刻で異常な ひずみが出ていないかひずみ記録を調べたが，そのよ うなものは認められなかった。 


\section{5. 結び}

地震時に地盤表面部に生ずる 4 成分のひずみを観測 した，過去においては，水平面内での 3 成分の軸ひず みの観測を行ってきた．本文では，鉛直方向の地盤ひ ずみの観測を試み幾つかの地震について観測結果を得 た。そその結果，鉛直ひずみの時刻歴最大值は主ひずみ のものと同程度であり, また, 鉛直加速度と逆位相を 示すらしいことを見出した.

本論文の結果が而震設計に直接活用できるとは云い
にくい，しかし，地震時に生ずる地表面付近のひずみ を量的に例示しているので, 地中構造物や土構造物の 而震性や斜面の地震時安定の検討には基礎資料を与え ると考えている.

\section{参考文献}

1) 森地重暉，今村芳徳，高野工，小田幸平 : 地震時に生ずる 地盤ひずみの観測と結果についての考察，土木学会論文集， No.570/I40, pp.259-275, 1997.

(2006. 12.8 受付)

\section{EXAMINATION ON THE VERTICAL NORMAL STRAIN OBSERVED AT THE GROUND SURFACE DURING EARTHQUAKES}

\section{Shigeaki MORICHI, Yooichi KOMODA, Hirohisa INAGAKI and Hiroyuki ITAMI}

The strains induced within the grounds are comprised of six components. The strains induced at the ground surface are comprised of four components. The authors have been continuing the observations of the three strain components induced at the ground surface during the earthquakes. In this paper, the observation of the remaining strain component, i.e. vertical normal strain, induced at the ground surface was undertaken using a gauge length of 1 metre. Based on the several earthquake observations, it was found that the vertical strain is similar in magnitude to the principal strain at the ground surface, and also has a tendency to be completely out of phase in time scale with respect to the vertical accerelation. 